\title{
SERVITIZATION OF MANUFACTURING: SURVEY IN THE POLISH MACHINERY SECTOR
} pages: $20-33$

\author{
JUSTYNA KOZŁOWSKA
}

\begin{abstract}
A B S T R A C T
Servitization in developed countries is an increasingly popular strategy for building a competitive advantage. Its level varies depending on different market conditions as well as between sectors. The Polish economy is that of a developed country, but still, its level of development is slightly lower compared to the most developed countries. The current state of knowledge indicates that the machinery manufacturing sector usually characterises the highest level of servitization in comparison to other manufacturing sectors. To the author's knowledge, no study on the servitization of Polish manufacturing companies has been conducted. Therefore, the main objective of this paper is to fill the gap by analysing and evaluating the level of servitization in manufacturing companies operating in the Polish market. Aiming to assess whether the Polish manufacturers follow the global trends of servitization, the questionnaire survey was conducted with 150 machinery manufacturers operating in the Polish market. The survey was performed using the Computer-Assisted Telephone Interviewing (CATI) technique between May and July of 2018. The results showed that in surveyed companies, the level of servitization, which was assessed based on a range of the most frequently provided services, was rather low. Although most manufacturers offer services to their customers, these services mostly support their products, and the revenue derived from the services constitutes a comparatively small part of the company's total revenue. This paper makes two types of contribution to the development of research in the field of servitization. First, the study on the servitization of the Polish manufacturing companies revealed that in a country with the welldeveloped economy, industrial enterprises still rely on manufacturing rather than service delivery. And the potential for services is not yet recognised. Secondly, the original model for classifying the level of product and service integration in the activity of a manufacturing company is proposed. The model requires empirical verification and further studies. Nevertheless, it stands for a theoretical contribution to the research field of servitization.
\end{abstract}

KEY WORDS

servitization, product-service systems, product-service integration, machinery sector

10.2478/emj-2020-0002
Corresponding author:

Justyna Kozłowska

Bialystok University of Technology, Poland ORCID 0000-0001-5164-4023 e-mail: j.kozlowska@pb.edu.pl

\section{INTRODUCTION}

The phenomenon called servitization became a fact in the 21st century, and now, it is difficult to discuss it as the world economy is largely based on services. Not only does servitization mean an increase in the importance of the service sector of the economy, but it also describes an increase in the importance of service functions in other sectors (Szukalski, 2004). In particular, and also in industries focused so far on the manufacturing of material products, a change 
into more service-oriented business models may be observed $^{1}$. The effect of these changes is a shift in the focus of whole economies of most highly developed countries towards services or, in other words, towards functional economies. In a functional economy, the object of trade is the usefulness or functionality of a manufactured material product or service. From the manufacturing company's point of view, there are several reasons for such changes. On the one hand, drivers of servitization often come from outside of a company. The change towards servitization may be the answer to client needs or global trends (Goedkoop et al., 1999). Processes occurring in the global economy, as well as the situation on the local market, often force the direction of the development of enterprises. The growing power of customer demands also significantly influences enterprise decisions. In many industries, traditional mass production is changing into the manufacturing of unique products, the composition of which is tailored to specific customer needs (Kovács \& Kot, 2016). The functionality of a material product or its availability is a more advantageous and desirable solution, both from the point of view of economy and ecology ${ }^{2}$, as well as from the point of view of the customer (Kronenberg \& Bergier, 2010; Vezzoli et al., 2014). The concept of sharing economy also brings new opportunities for manufacturers of material products due to the development of digital technologies (Grybaite \& Stankevičienè, 2018). In consequence, services gained more importance as a crucial component of the final offer of manufacturing companies.

On the other hand, the idea of and the need for change arise inside the company. Building innovative strategies and evaluation of the business model determine the development of the company (Dębkowska, 2017). Thus, to seek and create new strategic possibilities, companies systematically evaluate their resources and capabilities in terms of improvement and development. Identification of a new alternative way to satisfy a customer by anticipating the emergence of new needs allows building strategies which ensure long-lasting competitive advantage and

\footnotetext{
1 The share of the added value generated by the service sector in some countries reaches almost $90 \%$ of the total added value of a given country (Luxembourg - 86.9\%, Malta - 85.1\%). In Poland, it has been about $60 \%$ of GDP for several years, for example, in 2017, it was $63.9 \%$ of GDP (Rynek ..., 2018).

2 The inclusion of services in the offerings of companies from the industrial sector results in the more effective use of products manufactured with more optimal use of materials and energy consumption throughout the product life cycle (Kronenberg \& Bergier, 2010).
}

develop new innovative business models. Also, new strategic possibilities may be identified by a comprehensive analysis of the environment (from a micro and macro perspective). The analysis of the environmental conditions by increasingly popular futureoriented methods (e.g., foresight analysis methods ${ }^{3}$ ) helps to identify trends and opportunities in the nearest or a more distant environment. Expanding the offering portfolio with additional services, offering a bundle of products and services, or even replacing the sales process with leasing, renting or sharing the product for a certain period, allow the manufacturing company to gain: (i) new customers for whom the product price is a purchase barrier, and (ii) to strengthen the relationship with the existing customers (Mont, 2002). For a number of manufacturing enterprises (e.g., IBM, Royce Rolls or Xerox), the change towards a new business model based on the provision of services was an extremely successful strategic choice (Kozłowska, 2015).

The scope and scale of servitization vary both within the sector and across countries. The Polish economy is that of a developed country, but still, its level of development is slightly behind the most developed countries. Predictably, manufacturing companies are in the initial stages of change towards servitization, which is already more noticeable in highly developed countries. But to the author's knowledge, no such study has been conducted in Poland, which indicates a research gap. Consequently, one of the objectives of this paper is to analyse and evaluate the level of servitization in manufacturing companies operating in the Polish market. This study focuses on the manufacturing sector of machinery and equipment, in which the acquisition of goods creates a bond between a customer and a seller or a manufacturer, which lasts for several years through warranty or maintenance services. This encourages producers to enrich product offerings with complementary services or make further steps into servitization. A pilot study conducted by the author in 2016, covering the analysis of offers (in generally available catalogues, documents, and websites) of 100 enterprises operating in the Polish machinery sector, showed that the vast majority of entrepreneurs had at least one type of service in the offer (Kozłowska, 2017), and less than 10\% of the

\footnotetext{
3 Application of different foresight methods in the environment analysis can be found, for example, in works by Nazarko et al., 2017a; Nazarko et al., 2017b; Nazarko \& Kononiuk, 2014; Kononiuk \& Magruk, 2015; Szpilko, 2014; Ejdys et al., 2019; Gudanowska, 2014.
} 
sampled enterprises offered broad packages containing more than six types of services. Few entrepreneurs of the Polish machinery sector integrate service functions with manufactured products. At the same time, only occasionally, $3 \%$ of the surveyed sample focus their activity exclusively on the manufacturing of products. Then, it can be assumed that service provision will be gaining more importance in Polish industrial sectors, as it happens in other countries that have more developed economies. It seems interesting whether the level of servitization differs significantly from other markets. The results of this study should provide an answer to this question. During the literature studies, the other research gap was identified. No model for assessing the level of servitization of companies based on quantitative research results has been found in the literature. Usually, such level is evaluated based on the results of the case study or other qualitative research methods. The author proposes an original model for classifying the level of product and service integration in the activity of a manufacturing company, which may be used for data gathered in the surveys.

The paper is structured as follows. The first part of the article presents the results of the literature review connected to the main concept of the integration of products and services in manufacturing as well as the scope of this phenomenon in different countries and markets. Then, the research methodology of this study is described. The author conducted a survey of the Polish machinery manufacturers using the CATI technique and a few in-depth interviews with experts within the servitization field. Then, the research results related to the level of the product and service integration are presented. The last part of the paper summarises the obtained results, explains the limitation of the study, and indicates the directions for further research.

This research is a part of studies conducted within the scientific project Methodology of strategic analysis of the company for the purposes of productservice integration financed from the funds of the National Science Centre, Poland.

\section{LITERATURE REVIEW}

The idea of integrating material products with services emerged against the background of the concept of sustainable development and circular economy as well as related research trends and as a result of changing market conditions. Technological progress and the globalisation of the economy have intensified competition, especially in emerging economies, where production costs are much lower compared to highly developed countries. According to research by $\mathrm{Wu}$ et al., US manufacturing companies would have to cut their production costs by $30 \%$ to compete with Chinese manufacturers (Wu et al., 2006). Moreover, the competitive impasse caused inter alia by the declining rate of return on long-term continuous investment in product innovation, which key industrial players can quickly see and copy, does not offer an opportunity to build a strong competitive advantage in the long term. As a result, in some markets, such as computer hardware, software, medical devices, and capital goods, a decreasing variety of product offerings can be observed (Shelton, 2009). The search for new instruments of competitive advantage is also driven by the decreasing demand for traditional industrial products and the short-term nature of technological novelties (Payne, 1996). In such a highly competitive environment, many companies face increasing uncertainty about income streams and volatility in input prices. The ease of production in low-cost countries and increasingly severe environmental regulations are just some of the factors that impede the functioning of markets. The development of the operational capacity to meet these challenges is crucial to improve the competitiveness of industrial companies. In response to market challenges, manufacturing industry leaders are increasingly complementing their product offerings with innovative services that increase the overall value for customers. Services are experiences rather than things (Jarocka \& Wang, 2018). Therefore, personalised offerings, which include a wide range of services and allow creating new customer relationships as well as building a stable competitive position, are much more difficult to copy and imitate by competitive companies than innovations in production technology.

The phenomenon of product-service integration is closely related to such research fields as productservice systems (Goedkoop, 2004; Mont, 2004; Tukker, 2004) or industrial product-service system (Meier et al., 2010), servitization (Neely, 2007) or servitization of industry/manufacturing, serviceoriented products (Tan, 2010), hybrid offerings (Ulaga \& Reinartz, 2011), product-service offerings (Gaiardelli et al., 2014), integrated solutions (Shelton, 2009) or product/service solutions (More, 2013), but also as eco-efficient services, functional sales or a functional product (Tan, 2010). Concepts behind 


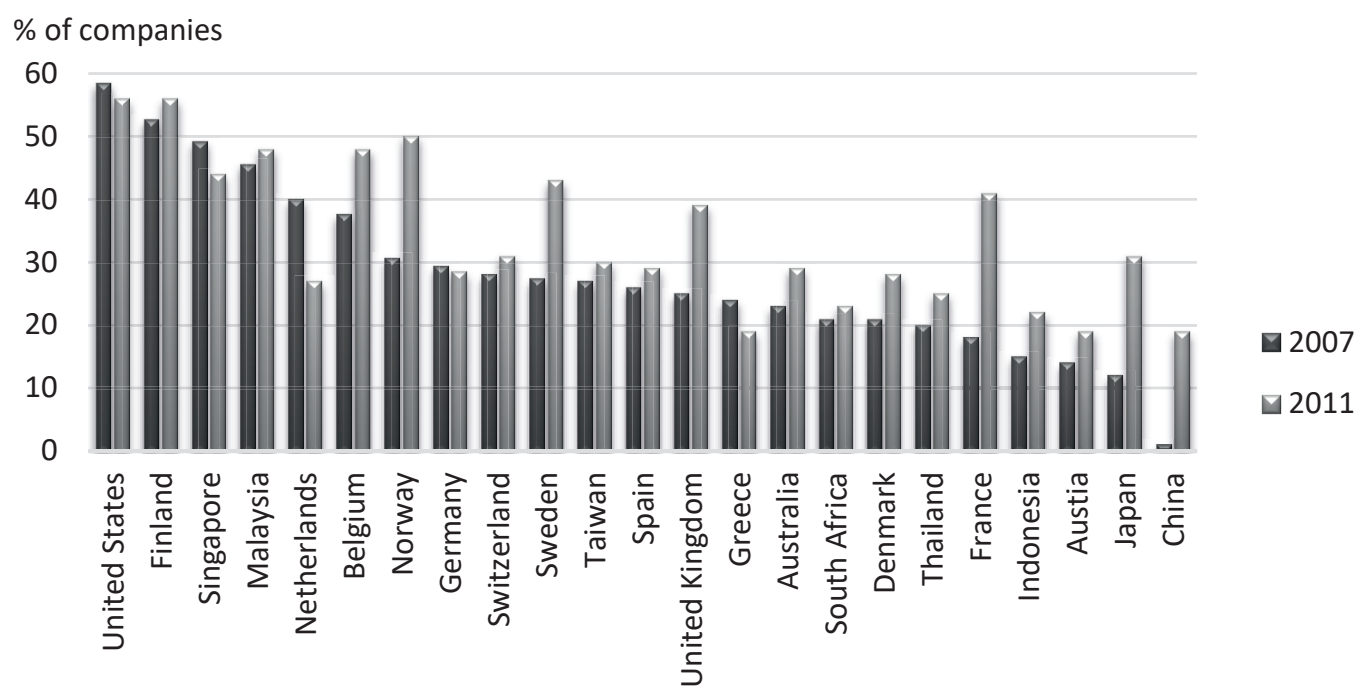

Fig. 1. Percentage of manufacturing companies with an integrated product and service offerings Source: elaborated by the author based on (Neely, 2008; Neely et al., 2011).

these terms often have the same background and ideas, while differing only by details. However, the most common terms that have appeared in the scientific literature for several years were "servitization of industry/manufacturing" and "product-service systems (PSS)." It should be mentioned that some researchers treat these terms as synonyms (Paslauski et al., 2016; Lightfoot et al., 2013) or elements of the same concept ${ }^{4}$. Servitization may be defined as offering market packages or "bundles" of customerfocussed combinations of goods, services, support, self-service, and knowledge, in which services begin to dominate (Vandermerwe \& Rada, 1988). Productservice systems are the most advanced solutions, which are understood as an integration of tangible products and intangible services into one solution/ system to jointly satisfy customer needs (Goedkoop et al., 1999). The servitization, however, starts with extending a product offer with complementary services, which are product-oriented. Afterwards, useoriented and, finally, result-oriented services are proposed to clients (Tukker, 2004). In this way, as a result of the servitization process, services substitute the sale of the physical products and are immanently joined with the product in one offering/solution delivered to clients.

The literature review conducted by the author showed that the studies analysing the phenomenon of industry servitization were undertaken in many countries around the world. In the area of servitization and PSS, qualitative research predominates with

\footnotetext{
4 According to Baines et al., PSS are a special case (stage) of the process of servitization (Baines et al., 2007).
}

case studies being the most commonly used technique $^{5}$. Quantitative studies that allow the analysis of trends and the progress of servitization processes as well as their scope in various industrial sectors in different countries or globally were undertaken by several authors (Qu et al., 2016). Quantitative surveys on large samples (dozens or more) are limited and usually carried out as part of large international servitization projects or conducted on data retrieved from thematic databases and public reports.

The results of the research by Neely on a global analysis of trends in the manufacturing sector in 2007 are among the most frequently quoted in literature. Neely analysed over 12000 enterprises employing over 100 employees and operating in the manufacturing industry, catalogued according to US SIC codes $10-39$ (from the extraction of metals to the production of various types of products). Data for the study were taken from the OSIRIS database. The percentage of producers, qualified by Neely to the group that offered integrated product and service solutions, according to data from 2007 and 2011, is presented in Fig. 1. The researcher also identified 13 forms of services offered by production companies, distinguishing the following types of services: consulting, design and development, financial, installation and implementation services, leasing, maintenance, and technical support, outsourcing and service, organisation of procurement, management and real estate trade, distribution, transport solutions and transport services (Neely, 2007).

\footnotetext{
${ }^{5}$ Among 2267 publications related to servitization and product and service systems in the found in the WoS database, 546 (around 24\%) were case studies.
} 
Neely's research demonstrated that services were offered by approximately $30 \%$ of global manufacturers that have more than 100 employees. In addition, there was a clear correlation between the servitization of the manufacturing sector and the level of development of the local economy as highly developed economies generally had more manufacturing companies offering integrated products and services compared to industrialised countries. Moreover, the total revenues of enterprises that offered both products and services constituted the major part of all revenues in the studied sample while representing a much smaller group of companies. Among the largest corporations, relatively more offered integrated services than those dealing exclusively with the production of goods, and revenues from services for many companies showed relative stability over the years. Noticeable is an increase in the percentage of manufacturers in China who provide integrated product-service offerings. It has risen from less than $1 \%$ (in 2007) to around 20\% (in 2011). Such significant and rapid change may indicate that producers from China want to step out of the role of a global manufacturing base, focusing on manufacturing activities with low added value, and follow global trends in servitization (Neely, 2008).

Research conducted in Europe within the T-REX project (Lifecycle Extension Through Product Redesign and Repair, Renovation, Reuse, Recycle Strategies for Usage \& Reusage-Oriented Business Model) in 2007-2013 with 95 European manufacturers of machines, means of transport and automatic devices revealed that the vast majority of the income of the surveyed manufacturers came from the sale of products. Service provision generated only about $12 \%$ in the machinery and automatic equipment sector and about $40 \%$ in the transport manufacturing sector. In addition, the survey results showed that advanced services, such as leasing, rent, warranty extensions, renovation and maintenance contracts, were rare and sometimes ignored by the industry (Adrodegari, 2015).

Above-described research was international. Many researchers undertake analyses of the servitization processes in local markets.

According to research by Crozet and Milet on the French market, $83 \%$ of companies registered in the industrial sector provided services to third parties, and nearly one-third of these producers sold more services than goods. The survey covered a relatively large sample of more than 635000 French manufacturing companies, whose share of the revenue from the provision of services in the total sales changed by more than 11\% between 1997 and 2007. This percentage increased steadily over the analysed period by more than 10\% between 1997 and 2001, and by almost 3\% between 2003 and 2007. However, twothirds of manufacturers derived less than $20 \%$ of their incomes from services. At the same time, around 30\% of French manufacturers derived over $80 \%$ of their income from service provision. The authors concluded their research work by stating that the servitization of the French manufacturing sector was driven by the dynamics of the development of enterprises and not by the sector in general (Crozet \& Milet, 2017)

In 2012, a study carried out in Spain by Santamaria, Nieto and Miles showed that almost 20\% of the surveyed companies innovated their activity by adding new services. Spanish manufacturing companies showed that sectors using advanced technologies, including both machinery and information technologies, also had more service innovation than sectors using medium-advanced technologies (Santamaria, Nieto \& Miles, 2012).

The research conducted by Neely on a large sample of 4067 German manufacturing companies revealed that $25 \%$ of them could be classified as servitized. The authors analysed enterprises having more than 100 employees. The level of servitization was assessed based on the text analysis of "business description" in the Capital IQ database. The data suggested that the highest servitization level was represented by industrial sectors (around 40\% of the research sample), from which the construction and engineering industry seemed to be most highly servitized with $56.30 \%$. The next highest level of servitization was observed in the sectors producing construction and farm machinery (50.88\%), heavy electrical equipment (49.25\%), aerospace and defence (49.09\%), and industrial machinery (42.37\%). The author also showed that the levels of servitization increased with firm size. Over $40 \%$ of the largest German manufacturing firms were servitized (Neely, 2013).

Huxtable and Schaefer published the results of a UK study in $2016^{6}$. Around $75 \%$ of analysed manufacturing companies derived less than $40 \%$ of their revenues from services, which, in the light of the literature studies carried out by the authors, led to the conclusion that there were still opportunities

\footnotetext{
6 The research included the analysis of generally available documents and reports of 57 companies operating in the UK.
} 
and the developmental potential in the field. Moreover, they argued that the Industry 4.0 concept was related and/or influenced the servicing processes. It is possible to benefit from offering Industry 4.0 services, but attention should be paid to the existence of significant economic risk factors that are related to the difficulty in estimating the costs of providing services in the long term (Huxtable \& Schaefer, 2016).

In 2016, studies on servitization were also carried out in Italy ${ }^{7}$. On average, $37 \%$ of medium-sized manufacturing companies in Italy offered different types of service components. The size of the company corresponded with the percentage of integrated offerings, i.e., the bigger the company, the higher the percentage. Also, the highest level of servitization (measured in terms of the size of the range of services offered and their nature) was observed in the machinery and metalworking sectors (Mastrogiacomo et al., 2017).

Danish researchers Raja and Frandsen noted that most analyses focused on servitization strategies in the western part of the globe, among companies operating in developed economies. Therefore, Raja and Frandsen conducted a case study on a Danish manufacturer of capital goods who had intensively developed its operations in the Chinese market through a subsidiary. The survey consisted of 22 interviews conducted at the company's headquarters and in its Shanghai branch, with employees at various levels of manufacturing and service delivery. According to Danish research, the implementation of service strategies requires the organisation of a network of cooperation with local partners. One of the key aspects of servitization is to establish and maintain appropriate relationships with customers, which can only be ensured by cooperation with local partners who have knowledge of the local market and customers. The offering of advanced services and solutions often requires additional investments in the development of the skills of external partners (Raja \& Frandsen, 2017).

Just recently, the study on service innovation and servitization has been carried out in Japan. It showed that the degree of servitization differed significantly across industries. The highest level has been observed in the transportation machinery industry (approx. $1.6 \%)$, while in the leather industry there were no signs of servitization. In general, the servitization

\footnotetext{
7 The survey was carried out on a relatively large group of more than 9000 medium-sized Italian production companies using textual analyses of the companies' activity descriptions available in the AIDA database.
}

ratio is high in the processing assembly industries, which have closer contacts with end consumers. The material industries (providing industrial materials, etc.) represent relatively low degrees of servitization (Shikata et al., 2019).

Based on the above literature review, it can be stated that in many countries and markets, the servitization processes are visible, but to a somewhat different extent. The scope of servitization also differs between sectors. In industries, such as machinery manufacturing, metal processing, automotive or high-technology industries, services are more common and more advanced than in in the clothing industry, for example. However, it is difficult to compare research results from different markets as they were conducted on a different scale (the chosen sectors or in manufacturing companies generally), with different research methods (analysis of data available in reports and databases or data obtained in interviews and surveys), assumptions or limitations. Nonetheless, no such study has been conducted in Poland. This was the main prerequisite to undertake the research of the Polish market in the context of servitization. Its results are presented in the following sections of this article.

It should be noted that most studies described above were conducted using data derived from different databases. Companies were classified as servitized mainly on the basis of the description of the business activity mentioning services as a part of it or if the company reported that some share of the total revenue came from services. In the author's opinion, both aspects (service offer and the share of income from service in the total income) should be considered while evaluating the progress of the servitization in manufacturing. Therefore, an original model for classifying the level of product and service integration in the activity of a manufacturing company was developed and described in the third part of this paper.

\section{RESEARCH METHODS}

The survey was carried out in May-July 2018, using the Computer-Assisted Telephone Interviewing (CATI) technique and a structured questionnaire as a tool. The CATI technique was chosen because of its advantages, including the continuous monitoring of the survey and the quality of the collected data, the short time needed to conduct interviews, the possibility to directly record data in an electronic form, the standardisation of telephone interviewing techniques, 
and the minimised risk of errors and data gaps in final results. The obtained data allowed to assess the level of servitization in Polish machinery manufacturing companies. Due to the exploratory aim of questions, nominal and interval scales were used. To measure the frequency of service delivery by a company, a 7-point Likert scale was applied. Telephone interviews were conducted among managers or other decision-makers in 150 enterprises operating in the Polish machine and equipment manufacturing sector. According to the data of the Central Statistical Office (GUS), section $28 \mathrm{C}$ (industrial processing) has the total of 9595 registered economic entities (BDL, 2017). The size of the research sample was set at 150 due to the financial feasibility as well as technical and organisational possibilities. It is increasingly more difficult to convince entrepreneurs to participate in full telephone interviews, especially considering a limited timescale. A random selection of respondents and the size of the selected statistical sample allow generalizing conclusions for the entire population of machinery and equipment manufacturers with a maximum error of $8 \%$ at a confidence level of $95 \%$. The study results were also discussed with several experts with academic and business experience in servitization. Experts from the academic environment had at least several years of experience in observing and analysing the economic situation on the Polish market, and, in particular, in the industry sector. The business environment experts represented a medium or large enterprise, which offered a varied scope of services to clients, performing managerial functions in their organisation and having a minimum of five years of experience in the industry. The purpose of qualitative research was to confirm the results of quantitative research and to deepen the knowledge about the reasons for taking up service activities by manufacturing companies and factors influencing the process of servitization in Polish enterprises.

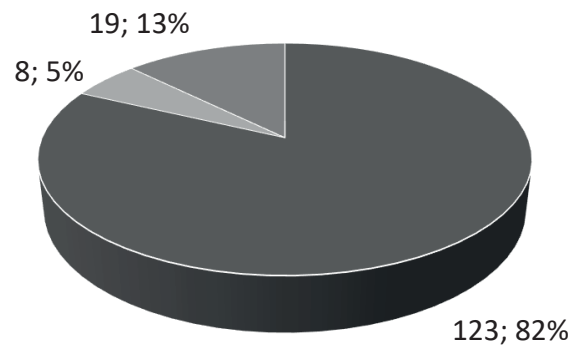

\section{RESEARCH RESULTS}

The surveyed enterprises were located throughout Poland. Each province (voivodship) was represented by at least three respondents. Among the surveyed machinery and equipment manufacturers, more than half in terms of size, measured by the number of employees, were medium enterprises (52\%). The next largest group (27\%) were small enterprises employing from 10 to 50 employees. Manufacturers employing more than 250 employees constituted $19 \%$ of the surveyed sample, while those qualifying as micro enterprises, i.e. employing less than ten people, constituted only $2 \%$ of the surveyed sample.

The basic part of the questionnaire was questions related to the service provision. According to the survey results, over $80 \%$ of machine and equipment manufacturers offered their customers services related to their products (Fig. 2). Around 13\% delivered services unrelated to the manufactured products. Only 5\% of companies did not perform any kind of service to their clients.

Within the framework of the research, the assessment focused on the scale of the frequency of the use of different types of services. This part of the questionnaire was filled in only by entrepreneurs providing services related to manufacturing (i.e., 123 respondents). Based on the pilot study conducted by the author in 2016 and the literature review, a catalogue was prepared to list 16 services provided by entrepreneurs operating in the sector of machinery and equipment manufacturing. The catalogue of services included: pre-sales consultations, financial support (loans, instalments), transport, assembly and/or implementation, training and technical advice after the sale of products, warranty after-sales service, post-warranty after-sales service, maintenance and technical support, modernisation, repairs, regenera-

\footnotetext{
- The services provided are closely related to the production activity

- The services provided are not related to the production activity

- No performance of any services
}

Fig. 2. Structure of the research sample in terms of services delivered 
tion, disposal, scrapping and/or recycling of waste product (equipment/machinery), monitoring, research, expertise, rental, leasing and a vast range of so-called industrial services (machining, milling, cutting, bending etc.). During the interview, respondents were asked to assess the frequency of providing certain forms of services on a scale from one to seven, where one meant that the given services were "not provided by the manufacturer at all," while seven meant that they were provided "very often (several times a month/daily)." The results are presented in Table 1. In the machinery industry, the standard services were warranty and post-warranty. Over $80 \%$ of the respondents had this type of service in their offer, and over $75 \%$ carried out warranty service activities several times a month. Almost as frequently, customers of the surveyed enterprises (76\%) used the consultation service to adjust the product to their needs and even to design machines or devices in detail. A relatively large group of manufacturers (70\%) provided maintenance and technical support services for their products. Due to the machinery park, manufacturers used the potential of their production halls through the implementation of industrial services, which included such services as cutting, bending, milling, machining, and other methods. Over $60 \%$ of the surveyed companies provided these services very often. Among the least frequently offered forms of services were leasing, financial support in the form of credit or instalment payments and rental of machines. Additionally, producers also indicated the following services as relatively frequently provided and not included in the questionnaire: design, 3D modelling and visualisation, start-up of the production line, logistic services (supply, storage, storage, warehousing, completion of deliveries), audits, testing and risk analysis and construction office outsourcing.

In terms of the revenue from the provision of services, the largest group of respondents (52\%) declared that the income constituted less than 15\% of the total revenue, and another $17 \%$ reported the revenue share from services of $15 \%$ to $20 \%$. The other surveyed producers (about 30\%) achieved more than

Tab. 1. Frequency of services provided by the surveyed manufacturers of the machine industry

\begin{tabular}{|c|c|c|c|c|c|c|c|c|}
\hline \multirow[t]{2}{*}{ SERVICE TYPE } & \multicolumn{8}{|c|}{$\begin{array}{l}\text { ASSESS ON A SCALE FROM } 1 \text { TO } 7 \text {, HOW OFTEN THESE SERVICES ARE PROVIDED, IF: } \\
1 \text { - MEANS THAT THESE SERVICES ARE NOT PROVIDED AT ALL IN THE COMPANY, } \\
7 \text { - MEANS THAT THESE SERVICES ARE PROVIDED VERY OFTEN } \\
\text { (SEVERAL TIMES A MONTH/DAILY) } \\
\text { PERCENT [\%] }\end{array}$} \\
\hline & 1 & 2 & 3 & 4 & 5 & 6 & 7 & SuM \\
\hline Warranty after-sales service & 19 & 2 & 3 & 1 & 3 & 23 & 49 & 100 \\
\hline Post-warranty after-sales service & 22 & 1 & 2 & 1 & 5 & 22 & 47 & 100 \\
\hline Pre-sales consultations & 24 & 3 & 3 & 3 & 7 & 15 & 44 & 100 \\
\hline Maintenance and technical support & 30 & 0 & 3 & 6 & 11 & 19 & 31 & 100 \\
\hline $\begin{array}{l}\text { Industrial services (machining, milling, cut- } \\
\text { ting, bending and other manufacturing } \\
\text { services) }\end{array}$ & 30 & 3 & 1 & 2 & 11 & 20 & 33 & 100 \\
\hline Modernisation, overhauls, regeneration & 35 & 3 & 5 & 4 & 17 & 21 & 15 & 100 \\
\hline Assembly and/or implementation & 36 & 1 & 2 & 6 & 9 & 23 & 23 & 100 \\
\hline $\begin{array}{l}\text { After-sales training and technical advice for } \\
\text { products }\end{array}$ & 39 & 5 & 1 & 4 & 18 & 15 & 17 & 100 \\
\hline Transport & 42 & 5 & 5 & 3 & 9 & 19 & 17 & 100 \\
\hline Research, expert opinions & 59 & 4 & 5 & 8 & 7 & 13 & 4 & 100 \\
\hline $\begin{array}{l}\text { Disposal, scrapping and/or recycling of waste } \\
\text { product (equipment/machinery) }\end{array}$ & 70 & 3 & 1 & 5 & 12 & 7 & 3 & 100 \\
\hline Monitoring & 74 & 2 & 3 & 2 & 8 & 3 & 7 & 100 \\
\hline Maintenance & 79 & 4 & 2 & 5 & 5 & 3 & 2 & 100 \\
\hline Rental & 89 & 3 & 2 & 1 & 3 & 0 & 2 & 100 \\
\hline Financial support (loans, instalments) & 91 & 1 & 3 & 2 & 1 & 1 & 1 & 100 \\
\hline Leasing & 92 & 3 & 1 & 1 & 3 & 1 & 0 & 100 \\
\hline
\end{tabular}




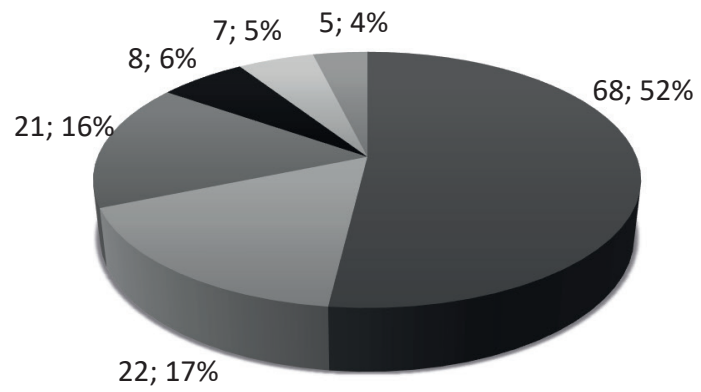

Fig. 3. Share of revenues from the provision of services in total revenues

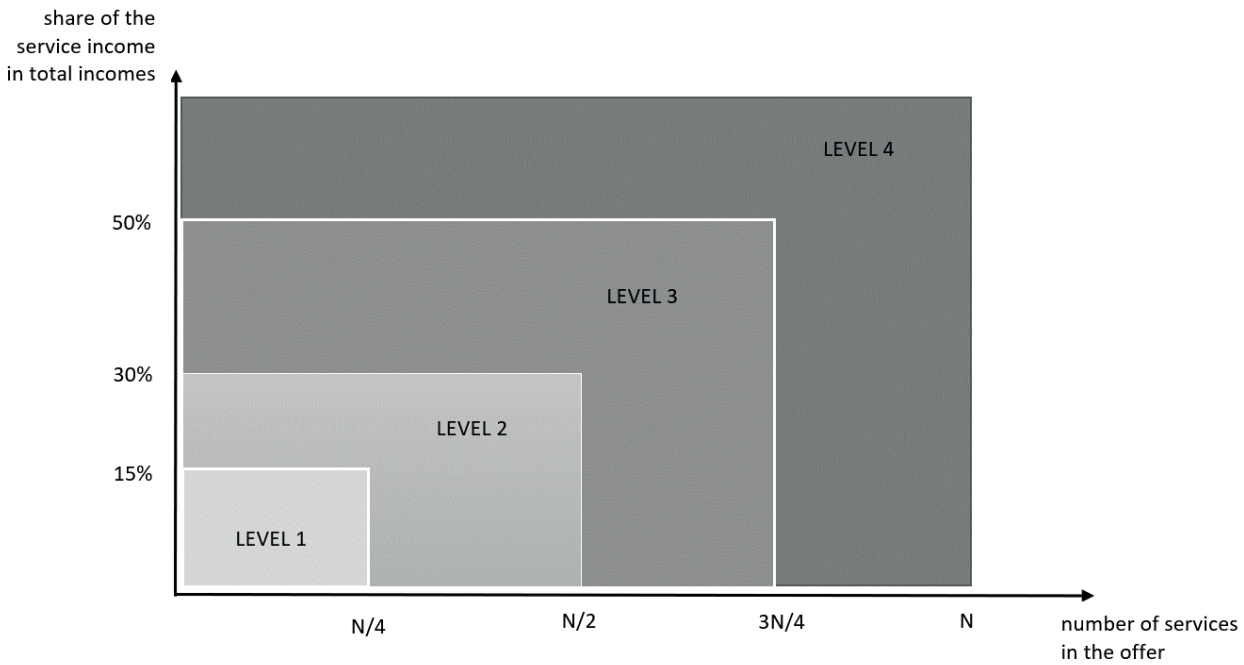

Fig. 4. Original model for classifying the level of product and service integration in the activity of a manufacturing company

$20 \%$ of their revenue from the provision of services, and the highest percentage of revenue from services in the total revenue of the company (i.e. more than $50 \%$ ) was shown by only $4 \%$ of surveyed producers who had production-related services in their offer (Fig. 3). In this case, the percentage shares refer to all producers providing services, including those unrelated to the manufacturing activity, i.e. 131.

Judging from the results of the analysis into service offers by Polish machinery and equipment manufacturers, the main focus is on the provision of services complementary to the manufactured goods. These are services characteristic for the first steps of servitization. Services characteristic for more advanced service providers within the manufacturing sector include the following from the analysed set: research and expert opinions, disposal, scrapping and/or recycling of waste product (equipment/ machinery), monitoring, maintenance, rental, and leasing. These are located at the bottom of Table 1, which is sorted according to the decreasing frequency of services provided by Polish machinery and equipment manufacturers. For each of these services, less than $25 \%$ of the surveyed companies (and for some, it is only a small percentage) reported the provision of these services with a frequency higher than a few times a month. On the other hand, over 60\% (and in some cases, even about $90 \%$ ) of the surveyed enterprises claimed that there were no such services in their offer. Therefore, it can be concluded that the Polish machinery industry still mostly has the basic model of servitization, in which the services provided constitute a complementary part of the offer and are mainly centred on the material product. More advanced models, including services substituting product acquisition, such as leasing or rental, or requiring a higher level of customer interaction, such as monitoring or maintenance, are rarely used on the Polish machinery market. Around $70 \%$ of surveyed companies reported that the share of revenue derived from service provision as at the most $20 \%$ of the total revenues of the firm. This also indicates that the machinery manufacturers in Poland still focus on manufacturing and the service provision is rather additional and occasional. 
To evaluate the level of servitization of surveyed companies based on collected data, the following model for classification is proposed. Scientific literature suggests no model for such classification, which would be applicable to the quantitative research results. The model (Fig. 4) assumes that the level of product and service integration can be measured using two dimensions:

- the percentage share of the revenue from services in the total revenue;

- service catalogue described by the number of services in the company offer, assuming the maximum number of $\mathrm{N}$ services identified for a given industry.

The number $\mathrm{N}$ of different types of services in the offering should refer to the specifics of the industry and include the maximum number of services identified for the examined industry. The first dimension - the percentage share of the revenue from services in the total revenue - is rather a popular measurement (used, e.g., by Shelton, 2009). In the model, the following thresholds of the share of the service revenue are set: $15 \%, 30 \%, 50 \%$, and more. And for the second dimension - the number of services in the company offer - one can assume the achievement of the next level of advancement when expanding the service offer by the number N/4 services (step: $25 \%$ ), where $\mathrm{N}$ is the maximum number of services identified in the offers of enterprises of a given industry.

For the machinery industry, 22 types of services were identified, i.e., 16 types of services were assessed in the questionnaire, and six additional types of services were proposed by the respondents. The classification of each object was carried out for two dimensions separately, and ultimately, the company was classified based on the higher result of the classification. Due to the model assumptions, it should be noted that the results are an optimistic rather than a pessimistic version of the actual level of servitization of machinery industry enterprises. Half of the companies represent the second level of servitization, while the highest level was reached by $3 \%$ of the surveyed manufacturers. Producers who were a part of this small group, showed high shares of the revenue from services, with a range of about 11 forms of services.

Since many researchers indicate a correlation between the servitization level and the size of the company (e.g., Mastrogiacomo et al., 2017; Neely, 2013), a contingency table was created for the two features (Table 3). It can be noticed that levels 1 and 4 are represented only by small and medium enter-

Tab. 2. Level of product-service integration of the surveyed enterprises according to the authors of the classification model

\begin{tabular}{|c|c|c|c|}
\hline LEVEL & CHARACTERISTICS OF THE LEVEL SETTINGS & $\begin{array}{l}\text { NUMBER OF } \\
\text { COMPANIES }\end{array}$ & $\begin{array}{c}\text { Percent } \\
{[\%]}\end{array}$ \\
\hline 1 & $\begin{array}{l}\text { Number of services }<6 \text { and the share of the service income in the total } \\
\text { income below } 15 \%\end{array}$ & 11 & 7 \\
\hline 2 & $\begin{array}{l}\text { Number of services between } 6 \text { and } 11 \text {, or the share of the service income } \\
\text { in the total income between } 15 \% \text { and } 30 \%\end{array}$ & 76 & 51 \\
\hline 3 & $\begin{array}{l}\text { Number of services between } 11 \text { and } 17 \text {, or the share of the service in- } \\
\text { come in the total income between } 30 \% \text { a } 50 \%\end{array}$ & 39 & 26 \\
\hline 4 & $\begin{array}{l}\text { Number of services }>17 \text {, or the share of the service income in the total } \\
\text { income more than } 50 \%\end{array}$ & 5 & 3 \\
\hline $\begin{array}{l}\text { Beyond qualifi- } \\
\text { cation }\end{array}$ & No services in the offer & 19 & 13 \\
\hline
\end{tabular}

Tab. 3. Contingency table of two variables: the company size and the level of servitization

\begin{tabular}{|c|r|r|r|r|r|}
\hline \multirow{2}{*}{$\begin{array}{c}\text { LEVEL } \\
\text { OF SERVItIZATION }\end{array}$} & \multicolumn{5}{|c|}{ COMPANY SIZE } \\
\cline { 2 - 6 } & MICRO & SMALL & MEDIUM & LARGE & \multicolumn{1}{c|}{ SUM } \\
\hline Level 1 & 0 & 6 & 5 & 0 & 11 \\
\hline Level 2 & 1 & 20 & 40 & 15 & 76 \\
\hline Level 3 & 1 & 5 & 23 & 10 & 39 \\
\hline Level 4 & 0 & 3 & 2 & 0 & 5 \\
\hline Beyond classifiaction & 1 & 6 & 9 & 3 & 19 \\
\hline Total & 3 & 40 & 79 & 28 & 150 \\
\hline
\end{tabular}


prises. Level 2 and 3 are dominated by medium manufacturers (over $52 \%$ and $58 \%$ of companies at a level, respectively).

At the same time, it is visible that all large companies represent level 2 or 3 of the product-service integration. The distribution of results for small and medium manufacturers is dispersed more. It may also be observed that small companies represent a lower level of the product-service integration in their activity. However, no clear correlation is suggested by these data. For the two variables, a chi-square test was also performed, to analyse the relationship between them, and no statistically significant relationship was found ( $\mathrm{p}=0.26$, chi-square $=14.63$ with $\mathrm{df}=12$ ).

\section{DISCUSSION OF THE RESULTS}

The survey results indicate that over $80 \%$ of Polish machine and equipment manufacturers offer their customers services related to manufactured products. This is a relatively high level compared to the global results received by Neely in 2007, which indicated that about $30 \%$ of producers with more than 100 employees offered services, or the results received by Italian researchers Mastrogiacomo, Barracecchia, and Franceschini in 2016, according to which about $37 \%$ of medium-sized manufacturing companies in Italy offered various types of service components. It should be noted, however, that in both cases, research was carried out in companies with different types of manufacturing activity, and the Italian researchers noted that the machinery and metal processing sectors were characterised by the highest level of servitization, measured by the range of services offered and their nature. On the other hand, the results of the research obtained by the author in relation to the results obtained by Crozet and Milet for the industrial sector in France show a very high degree of similarity in terms of the service activities in these markets. In the French market, more than $83 \%$ of companies registered in the industrial sector also provided services. Therefore, this result is almost identical to the one obtained by the author during the survey among Polish manufacturers of the machinery industry. It also turns out, that services are not a novelty among Polish machine manufacturers as the vast majority of surveyed enterprises (67\% of all providing any services) has been providing services since the beginning of their existence in the market. At the same time, even if services constitute an additional offer diversifying the company's activity and were already intro- duced during its operation in the market, they have been implemented in enterprises for over a dozen years. Among those producers who provide services, the vast majority has comparatively lengthy experience with this activity. Almost $80 \%$ have been providing services for over 15 years, and only $5 \%$ did so for less than five. But these are still mostly product-oriented services. So, the potential of more advanced services or service-oriented business models has not yet been recognised by Polish manufacturers. However, it can be observed that in general, the Polish market has been developing in recent years rather rapidly, and entrepreneurs usually try to compete with companies from around the world. According to the results of the Mitsubishi Electric Europe report, the machinery sector is one of the most innovative industries. Polish manufacturers in competition with producers of cheap industrial machines manufactured, for example, in China, offer such services as financing of purchases in cooperation with leasing funds, good service warranty, and post-warranty, the possibility of extending product life-cycle and renovating machines (Kołaczek, 2018). Therefore, it may be assumed that the servitization level of this sector will be rising in the nearest future.

It seems positive that a small percentage of enterprises represents level 1 of servitization, and a quarter of the sample $(26 \%)$ reaches level 3, i.e., generates over $30 \%$ of the revenue from the provision of services or expands the range of services and has several types of services in the offer. This may indicate that entrepreneurs see potential in service provision and decide to develop in this direction. It is obvious though that in general, the service provision by Polish machinery manufacturers is still a secondary source of income in relation to production.

The study results were presented and discussed with experts, who have either academic or business experience in the servitization field. They pointed out that the Polish market reacts to global trends with some delay. In terms of economic structure and technological level, it differs slightly from highly developed countries, in which servitization reaches higher levels of maturity:

Expert 1: “(...) First of all, in Poland, we have a dominant agricultural sector, and the industrial sector probably generates about $30 \%$ of employment. Secondly, we still have large resources in Poland when it comes to so-called cheap labour. We have a lot of production workers (...) That is why, I think, we have quite a gap to fill in comparison to most developed 
countries." Although experts see the product-service integration signs in the Polish industry:

Expert 2: “... the importance of production compared to services in Poland is generally higher than the statistical average in more developed countries (...) which is probably the result of a certain delay related to the economic transformation, as well as the geographical location of our country. Despite this, there are visible signs of following global trends. Currently, the potential of service activities and the process of servitization in Poland is beginning to be recognised among Polish enterprises, especially in certain industries and among younger managers."

Expert 3: "It is more observed in some industries, less so in others, but companies are beginning to pay attention to it."

Thus, the servitization trend may not be exploding now among Polish machinery manufacturers, but it is progressing and expected to increase in the future.

\section{CONCLUSIONS}

In the 21st century, services and the service sector gained greater importance which is also reflected by the growing attention to service functions in the industrial sector. In the framework of the study presented in this paper, the research review was conducted. It mainly focused on European efforts and showed that the level of servitization varied in different countries and different sectors of a country. The most prone to servitization was the machinery and metalworking industry as well as those industries that mostly relied on information technologies. The results of the survey conducted under the Polish market conditions showed that machinery producers focused more on manufacturing than on service provision. Although the vast majority of them performed services for a rather long time, these were mainly warranty and post-warranty after-sales services, pre-sales consultations, maintenance, and technical support and industrial services (machining, milling, cutting, bending and other manufacturing services). And the potential for more advanced services, which were use-oriented or result-oriented, was not yet recognised. The latest reports on the state of the machinery sector outlined the continuous improvement of the quality of cheaper industrial machines manufactured, e.g., in China. Thus services, especially those that substitute the purchase of prod- ucts, are likely to be of greater interest for manufactures and the servitization process will continue.

Obviously, the major limitation of this study is the range of the research - the survey targeted Polish manufacturers representing one certain sector. It means that it cannot be representative of the whole industry in Poland. The second limitation is the original model that was used to assess the level of product-service integration in surveyed companies. Though it seems to be constructed similarly to other methods and models for measuring the level of servitization, it is experimental and lacks an empirical verification. The share of the service income in the total income of the company was surely the most popular and widely recognised measurement of servitization in a manufacturing company, but the other dimension - the number of services and, in particular, its thresholds - needs to be verified and adjusted to the sector. In some cases, a low number of services means that the company specialises in its delivery or services are so deeply integrated into the offering that their components are difficult to separate or be counted, so in fact, the threshold may be much lower than it was assumed in the model.

Therefore, this study raises at least a few questions for further research: Whether and to what extent servitization processes occur in other Polish manufacturing sectors? What are the reasons behind the low level of product-service integration in Polish machinery manufacturing companies? Is it the reluctance of the customers or the lack of the need? Or could it be that manufacturers lack competencies in delivering more advanced services? Should the increase of the servitization level be expected in all industry sectors in the coming years? Likewise, the empirical verification of the proposed model for the classification of product-service integration seems to be a promising field for future research.

\section{ACKNOWLEDGEMENTS}

The research was conducted within the scientific project Methodology of strategic analysis of the company for the purposes of product-service integration (Project No. 2016/23/N/HS4/03547) financed from the funds of the National Science Centre, Poland. 


\section{LITERATURE}

Adrodegari, F., Alghisi, A., Ardolino, M., \& Saccani, N. (2015). From ownership to service-oriented business models: a survey in capital goods companies and a PSS typology. Procedia CIRP. 7th Industrial Product-Service Systems Conference - PSS, industry transformation for sustainability and business, 30, 245-250. doi: 10.1016/j.procir.2015.02.105

Baines, T.S., Lightfoot, H. W., Evans, S., Neely, A., Greenough, R., Peppard, J., Roy, R., Shehab, E., Braganza, A., Tiwari, A., Alcock, J. R., Angus, J. P., Bastl, M., Cousens, A., Irving, P., Johnson, M., Kingston, J., Lockett, H., Martinez, V., Michele, P., Tranfield, D., Walton, I. M., \& Wilson, H. (2007). State-of-theart in product-service systems. Proceedings of the Institution of Mechanical Engineers, Part B, Journal of Engineering Manufacture, 221(10), 1543-1552. doi: 10.1243/09544054JEM858

BDL - Bank danych lokalnych [Local data bank]. Retrieved from: https://www.bdl.stat.gov.pl

Crozet, M., \& Milet, E. (2017). The Servitization of French Manufacturing Firms. In L. Fontagne, \& A. Harrison, The factory-free economy: outsourcing servitization, and the future of industry, (pp. 111-135). Oxford, United Kingdom: Oxford University Press. Retrieved from: http://www.cepii.fr/PDF_PUB/wp/2014/wp2014-10.pdf

Dębkowska, K. (2017). E-services in business models of enterprises in the logistics sector. Business: Theory and Practice, 18(1), 79-87. doi: 10.3846/btp.2017.009

Ejdys, J., Gudanowska, A., Halicka, K., Kononiuk, A., Magruk, A., Nazarko, J., Nazarko, L., Szpilko, D., \& Widelska, U. (2019). Foresight in higher education institutions: evidence from Poland. Foresight and STI Governance, 13(1), 77-89. doi: 10.17323/25002597.2019.1.77.89

Gaiardelli, P., Resta, B., Martinez V., Pinto, R., \& Albores, P. (2014). A classification model for product-service offerings. Journal of Cleaner Production, 66, 507-519. doi: 10.1016/j.jclepro.2013.11.032

Główny Urząd Statystyczny [Statistics Poland] (2018). Rynek wewnętrzny w 2017 r. [Internal market in 2017], Warszawa. Retrieved from: http://stat.gov. $\mathrm{pl} /$ obszary-tematyczne/ceny-handel/handel/rynekwewnetrzny-w-2014-r-,7,20.html

Goedkoop, M. J., van Halen, C. J. G., te Riele, H. R. M., \& Rommens, P. J. M. (1999). Product Service Systems, Ecological and Economic Basics. Report Nr. 1999/36 submitted to the Ministry of Housing, Spatial Planning and the Environment (ministerial VAN) in The Hague, Netherlands. Retrieved from: https://www.researchgate.net/publication/293825611_Product_Service_systems_Ecological_and_ Economic_Basics

Grybaite, V., \& Stankevičienè, J. (2018). An empirical analysis of factors affecting sharing economy growth. Oeconomia Copernicana, 9(4), 635-654. doi: 10.24136/oc. 2018.031

Gudanowska, A. (2014), Technology mapping as a tool for technology analysis in foresight studies. 2014 IEEE International Technology Management Conference, Chicago, IL, 1-4. doi: 10.1109/ITMC.2014.6918613

Huxtable, J., \& Schaefer, D. (2016). On the Servitization of the Manufacturing Industry in the UK. Procedia CIRP. Changeable, Agile, Reconfigurable \& Virtual Production, 52, 46-51. doi: 10.1016/ j.procir.2016.07.042

Jarocka, M., \& Wang, H. (2018). Definition and classification criteria of logistics services for elderly. Engineering Management in Production and Services, 10(4), 65-75. doi: 10.2478/emj-2018-0023

Kołaczek, P. (2018). Rozwój przemysłu maszynowego w Polsce - Raport [Development of the machine industry in Poland - Report]. Mitsubishi Electric Europe B.V. (Sp. z o.o.). Retrieved from: https:// iautomatyka.pl/rozwoj-przemyslu-maszynowego-wpiolsce-raport/

Kononiuk, A., \& Magruk, A. (2015). Wild cards in Polish foresight practice. Procedia - Social and Behavioral Sciences, 213, 951-956. doi: 10.1016/j.sbspro.2015.11.510

Kovács, G., \& Kot, S. (2016). New logistics and production trends as the effect of global economy changes. Polish Journal of Management Studies, 14(2), 115-126. doi: 10.17512/pjms.2016.14.2.11

Kozłowska, J. (2015). Product-Service System in a manufacturing company strategy-a review paper. Economics and Management, 7(2), 48-56. doi: 10.12846/ j.em.2015.02.06

Kozłowska, J. (2017). Services in Machinery Manufacturing Sector in Poland. Procedia Engineering, 182, 350-358. doi: 10.1016/j.proeng.2017.03.110

Kronenberg, J., \& Bergier, T. (Eds.) (2010). Wyzwania zrównoważonego rozwoju w Polsce [Challenges of sustainable development in Poland]. Krakow, Poland: Fundacja Sendzimira.

Lightfoot, H., Baines, T., \& Smart P. (2013). The servitization of manufacturing. A systematic literature review of independent trends. International Journal of $\mathrm{Op}$ erations \& Production Management, 33(11/12), 14081434. doi: 10.1108/17410380910960984

Mastrogiacomo, L., Barraveccia, F., \& Franceschini, F. (2017). A general overview of manufacturing servitization in Italy. Procedia CIRP, The 9th CIRP IPSS Conference: Circular Perspectives on Product/Service-System, 64, 121-126. doi: 10.1016/j.procir.2017.03.010

Meier, H., Roy, R., \& Seliger, G. (2010). Industrial ProductService Systems - IPS2. CIRP Annals - Manufacturing Technology, 59, 611. doi: 10.1016/j.cirp.2010.05.004

Mont, O. (2002). Clarifying the concept of product-service system. Journal of Cleaner Production, 10(3), 237245. doi: 10.1016/S0959-6526(01)00039-7 
More, R. (2013). Marketing High Profit Product/Service Customer Solutions. Farnham, Burlington: Gower Publishing.

Nazarko, J., \& Kononiuk, A. (2014). Scenariusze $w$ antycypowaniu i kształtowaniu przyszłości [Scenarios in anticipating and shaping the future]. Wolters Kluwer, Warszawa 2014.

Nazarko, J., Ejdys, J., Halicka, K., Nazarko, Ł., Kononiuk, A., \& Olszewska, A. (2017a). Factor Analysis as a Tool Supporting STEEPVL Approach to the Identification of Driving Forces of Technological Innovation. Proceedia Engineering, 182, 491-496. doi: 10.1016/j. proeng.2017.03.142

Nazarko, J., Ejdys, J., Halicka, K., Magruk, A., Nazarko, Ł., \& Skorek, A. (2017b). Application of Enhanced SWOT Analysis in the Future-oriented Public Management of Technology. Procedia Engineering, 182, 482-490. doi: 10.1016/j.proeng.2017.03.140

Neely, A. (2007). The Servitization of Manufacturing: An analysis of Global Trends. Retrieved from: http://202.120.224.199/picture/article/110/00e3fddc-df0b-4e8b-96b6-89db9d-41a29d/8eb0e8f89868-479d-a425-cde8d5ca218d.pdf

Neely, A. (2008). Exploring the financial consequences of the servitization of manufacturing. Operational Management Research, 1(2), 103-118. doi: 10.1007/ s12063-009-0015-5

Neely, A. (2013). Servitization in Germany: An international comparison. Cambridge, United Kingdom: University of Cambridge. Retrieved from: https://cambridgeservicealliance.eng.cam.ac.uk/news/November\%20 2013\%20Paper

Neely, A., Benedetinni, O., \& Visnjic, I. (2011). The servitization of manufacturing: Further evidence. 18th European Operations Management, Association Conference, 3-6 July 2011 Cambridge UK. Retrieved from: https://www.researchgate.net/ publication/265006912_The_Servitization_of_Manufacturing_Further_Evidence

Paslauski, C. A., Ayala, N. F., Tortorella, G. L., \& Frank, A. G. (2016). The Last Border for Servitization. Procedia CIRP. Product-Service Systems across Life Cycle, 47, 394-399. doi: 10.1016/j.procir.2016.03.056

Payne A. (1996). Marketing ustug [Service Markting]. Warszawa, Poland: Polskie Wydawnictwo Ekonomiczne.

Raja, J. Z., \& Frandsen, T. (2017). Exploring the servitization in China. Challenges of aligning motivation, opportunity and ability in coordinating an external service partner network. International Journal of Operations \& Production Management, 37(11), 1654-1682. doi: 10.1108/IJOPM-12-2015-0755

Qu, M., Yu, S., Chen, D., Chu, J., \& Tian, B. (2016). Stateof-the-art of design, evaluation, and operation methodologies in product service systems. Computers in Industry, 77, 1-14.

Santamaria, L., Nieto, M. J., \& Miles, I. (2012). Service innovation in manufacturing firms: Evidence from
Spain. Technovation, 32, 144-155. doi: 10.1016/j.technovation.2011.08.006

Shelton, R. (2009). Integrating product and services innovation. Research-Technology Management, 52(3), 38-44. doi: 10.1080/08956308.2009.11657567

Shikata, N., Goto, S., \& Gemba, K. (2019). Servitisation of the manufacturing industry in Japan. Forum Scientiae Oeconomia, 7(3), 19-30. doi: 10.23762/FSO_VO L7_NO 3_2

Szukalski, S. M. (2004). Serwicyzacja gospodarki i industrializacja usług [Servitization of the economy and industrialization of services]. Handel Wewnętrzny, $4 / 5,47-53$.

Szpilko, D. (2014). The use of Delphi method in the process of building a tourism development strategy in the region. Economics and Management, 6(4), 329-346. doi: 10.12846/j.em.2014.04.24

Tan, A. (2010). Service-oriented product development strategies, doctoral thesis. Technical University of Denmark. Retrieved from: http://orbit.dtu.dk/fedora/objects/orbit:82986/datastreams/file_5177222/ content

Tukker, A. (2004). Eight types of product-service system: eight ways to sustainability? experiences from SusProNet. Business Strategy and the Environment, 13(4), 246-260. doi: 10.1002/bse.414

Ulaga, W., \& Reinartz, W. J. (2011). Hybrid Offerings: How Manufacturing Firms Combine Goods and Services Successfully. Journal of Marketing, 75(6), 5-23. doi: $10.2307 / 41406856$

Vandermerwe, S., \& Rada, J. (1998). Servitization of Business: Adding Value by Adding Services. European Management Journal, 6, 314-324. doi: 10.1016/02632373(88)90033-3

Vezzoli, C., Kohtala, C., \& Srinivasan, A. (2014). ProductService System Design for Sustainability. Sheffield, United Kingdom: Greenleaf Publishing Limited.

Wu, L., Yue, X., \& Sim, T. (2006). Supply clusters: a key to China's cost advantage. Supply Chain Management Review, 10(2), 46-51. 